\title{
Design and Fabrication of Grain Grading and Polishing Machine
}

\author{
Pravin S. Dahimiwal ${ }^{1}$, Akash S. Deshmukh ${ }^{2}$, Mangesh B. Ghanekar ${ }^{3}$, Yashraj S. Bhosale ${ }^{4}$ \\ Student, Mechanical Dept., STES's NBNSSOE, Pune, India ${ }^{1,2,3,4}$
}

\begin{abstract}
Agriculture plays a vital role in the Indian economy. Indian agriculture is at crossroads and one of the major challenges is to reverse deceleration in agricultural growth. The grains on handling after harvest contain various proportions of material other than grains (MOG) such as stone, pod, stem and dirt. Separation of the MOG is essential to upgrade the quality of food material. Grading result in reduced bulk of the material, high value products, safe and longer storage, more out-turn of better quality milled products. Improper grading usually results in cost loss. Cleaning helps to reduce bulkiness during subsequent post harvest operations. To remove straw pieces, unfilled grains and other foreign materials, cleaning and winnowing can be done manually, using wind energy or with the use of machines. In this project we are going to sort the food grains of different sizes, and also polish them at a time in three categories i.e. coarse, medium and fine grains. The wastage will be collected in the collector and impurities (if any) will also get removed with the help of fan/Blower. The slider crank mechanism is used for desired.
\end{abstract}

Keywords: MOG, Polishing Machine, Grain Grading, food grains, fan/Blower.

\section{INTRODUCTION}

The quality of the food grain we consume is of more importance, as people are becoming educated their demand for quality of grains is increasing. There is possibility of adulteration of food grains by the traders. Generally the quality assessment is carried by visual inspection which is manual process. In this work an image processing technique is used as an attempt to automate the process which overcomes the drawbacks of manual process. This paper provides the quality assessment of rice grains based on its size. Based on the size the grains are graded as (grade 1, grade 2 and grade3). The system is developed using 105 set of images and are classified using decision tree basedclassification technique. The demand for quality of food products we consume is increasing day by day. As the literacy rate is increasing in India so is the need for quality of food products is increasing. India is the second largest producer of rice grains first being China. As the production of rice is increasing so is the demand for its quality. This demand for quality of food grains is increasing because some of the traders cheat the shopkeepers by selling poor quality food grains which contains foreign particles like stones, sand, leaf, broken and damaged seeds etc. This kind of low quality of rice is sold without being noticed even and moreover there is no special scheme to find such poor quality grains. Therefore it is been a problem for both consumers and sellers. As the technology is growing wider people are adopting the new technologies rather than using the old techniques. The growth in technology is making people more demanding towards the things they use and consume, this is the reason why everything is becoming automated. The use of Image processing techniques for testing the quality of rice grains is inexpensive and is less time consuming. The quality of grain is tested based on its color, size, shape and texture features in this method. Further, biological methods (DNA technique etc) and chemical methods (alkaline tests etc) can be used for the identification of rice grain seed varieties and quality. But these methods are very expensive and time consuming. On the other hand the machine vision or the digital image processing is a non destructive method (i. e. after assessment the grains can be used), it is a very fast and inexpensive process compared to the biological methods. AGMARK is an organization which is used in rating of these food products. There are different organizations which also involve in rating of quality of food grains like ISO, FDA etc. These organizations help the famers to provide certificates for the quality of grains they produce. There is this AGMARK laboratory which is centrally located, which acts as the testing and certifying centre for the food products. Various tests are conducted in these laboratories which include biological tests, alkaline tests, test for pesticide content etc on products like groundnuts, maize, wheat, jowar etc.

\section{PROBLEM DEFINITION}

As India is a country where agriculture based economy is there but due to environmental uncertainties the quality of food produced is lowered and hence farmer gets the lowered cost of the product. So the aim is to fulfil the market demand and also improve the quality of grains. Problems facing by the small grain grower while cleaning the grains are small grain grower cannot afford for high price machineries which is economically higher cost of the grain cleaning machine ranges from 65 thousand to one lakh based on single specifications and features. 


\section{Objectives of the Project}

1. To meet the new machinery that is used to perform different grain cleaners in the field of agriculture.

2. Such machine is not available for small food suppliers.

3. The main objective of the project work is to get the cleaned variety of grain.

4. To use sustainable and profitable production methods without using electricity.

5. Focusing on the quality of agricultural products.

6. Improving food grain quality.

\section{METHODOLOGY}

We have started the work of our project with literature review. After referring several papers we got many ideas. From these ideas we started doing rough design of our project. After doing rough design we will start calculation of different parts. Once the calculation is completed we will draw a 3d model in Auto CAD. By referring this 3D model we will buy the standard component required for the projects. After this we will start manufacturing work in workshop. By taking proper dimensions we will manufacture components one by one. Along with this electronics part will also be done. In electronics we will have to build controller circuit to get signal from pressure and make to make solenoid valve work. After this, assembly of different components will be done. Later testing will be started for getting various results. Simultaneously rough draft will be prepared. After completing testing work fair report will be done and submitted.

\section{LITERATURE SURVEY}

1. "Fabrication of Pedal Operated Grain Cleaner" explained byChethana T. V and D. Ramesh

2. "Development of Grain Separator Machine"

explained by Nagesh S. And Dr. S .N. Lakshminarasimhan

3. "Design, fabrication and performance of a motorized cowpea thresher for Nigerian small-scale farmers" explained by

S. V. Irtwange

4. "Design and evaluation of a cleaning machine" explained by U.S. Muhammad, L.G. Abubakar, M. Isiaka and R.M. Davies

5. "Classification of Wheat Grains Using Machine Algorithms" explained by MeeshaPunn and NidhiBhalla

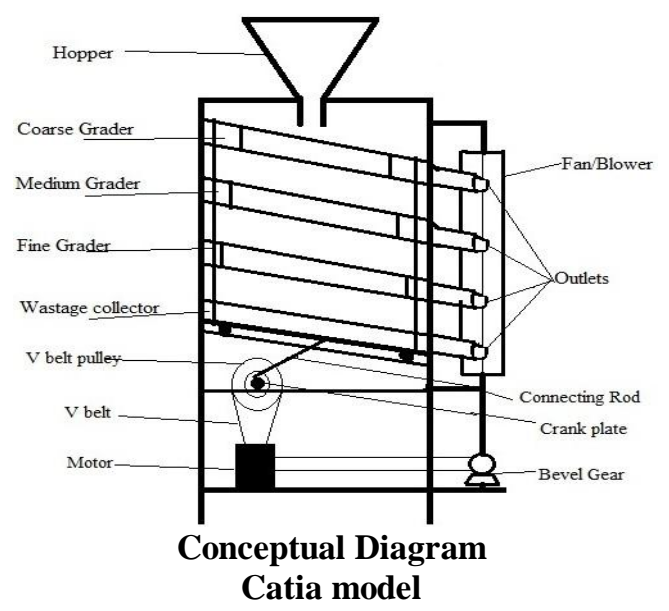

Components Used

1. Motor

(AC supply electric motor half H.P-Induction motor)

\section{V Belt and Pulley}

The power is transmitted by the wedging action between the belt and the V-groove in the pulley.

To transmit power from one shaft to another shaft

-Cast Iron Pulleys

\section{Slider Crank Mechanism}

The rotary motion of crank is converted into reciprocating motion with the help of this mechanism.

4. Grading and Polishing Trays

The tray has grading and polishing partition with total no of 4 trays.

\section{Hopper}

Storage container which is used to find out the mass flow rate of grains 


\section{Electrical Blower}

A standard electric blower is used to blow of the raw materials left in the machines

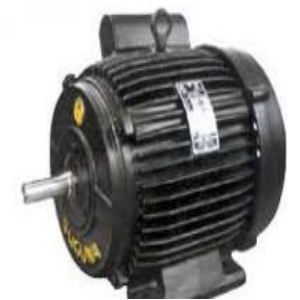

1.Motor

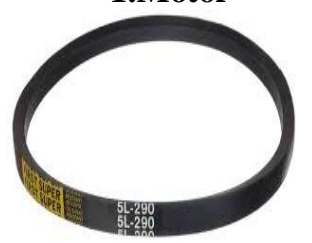

2. V Belt

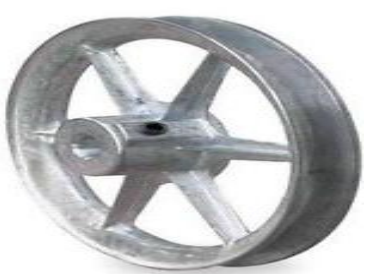

2. V Belt Pulley

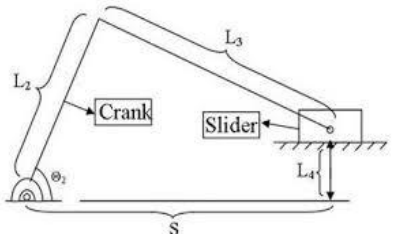

3.Slider Crank Mechanism
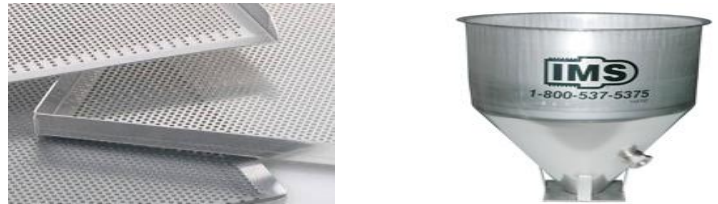

4. Grading and Polishing 5. Hopper Trays

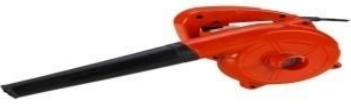

6. Electrical Blower

\section{Calculations:-}

Trollysize

$1 \mathrm{ft}$.

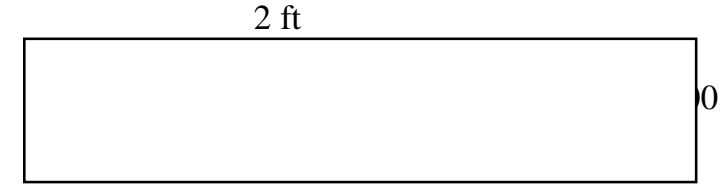

Height $=50 \mathrm{~mm}$

Length $=600 \mathrm{~mm}$

Width $-300 \mathrm{~m}$, Height $=50 \mathrm{~mm}$

Partition at $300 \mathrm{~mm}$ in length

Payload - 5kg

Mass of - all four tress $\quad 4 \mathrm{~kg}$

Total weight $=9 \mathrm{~kg}=9 * 9.81=88.29 \mathrm{~N}$

Stroke length $-\mathrm{h}=150 \mathrm{~mm}$

Obliquity ratio $\mathrm{n}=6=\mathrm{L} \mathrm{c} / \mathrm{r}$

Or

Stroke $\mathrm{h}=2 \mathrm{r}$

$\mathrm{R}=\mathrm{h} / 2=150 / 2=75 \mathrm{~mm}$

$\mathrm{r}=$ radius of crank

Length of connecting Rod

$\mathrm{Lc}=6 * \mathrm{r}=6 * 75=450 \mathrm{~mm}$

Total ratio $=28=4 \mathrm{D}$

For circular cross section $\mathrm{L} \mathrm{c} / \mathrm{p}=\mu \quad \mathrm{L} \mathrm{c} / \mathrm{D}=28$

Dia., of $\quad \operatorname{rod} \mathrm{L} \mathrm{c} / 28=\mathrm{D}=16.07=16 \mathrm{~mm}$

Sliding force for trolley

$\mathrm{F}=\mu * \mathrm{FN}$

Where, FN total body 
$=88.29 \mathrm{~N}$

Take

$\mu=0.02-\mathrm{scl}$

$\mathrm{F}=107658 \mathrm{~N}$

Total Force $=$ Total weight + sliding force

$=88.29+1.7658$

$=90.05$

$=90 \mathrm{~N}$

$\mathrm{K} . \mathrm{E}=$ Total force $*$ Stroke

$=90 * 0.150$

$\mathrm{K} . \mathrm{E}=13.5 \mathrm{Nm}$

Also

$\mathrm{K} . \mathrm{E}=0.5 *$ Total mass $*$ Velocity $^{2} \mathrm{C}^{1 / 2} \mathrm{mv}^{3}$

$13.5=0.5 * 9 * \mathrm{~V}^{2}$

$\mathrm{V}=1073 \mathrm{~m} / \mathrm{s} \quad$ Velocity of solider

Velocity of Slider $=$ Velocity of Crank $=1.73 \mathrm{~m} / \mathrm{s}$

$\mathrm{V}=\mathrm{r}$ w

$1.73=0.075 * \mathrm{w}$

$\mathrm{W}=23.066 \mathrm{rod} / \mathrm{r}$

$\mathrm{W}=2 \pi \mathrm{N} / 60$

$23.066=2 \pi \mathrm{N} / 60$

$\mathrm{N}_{2}=220.26 \mathrm{rpm}$

Total Force $=\mathrm{P}_{\mathrm{R}}=\mathrm{F}_{\mathrm{T}} * \mathrm{~V}$

$=90 * 1.73$

$\mathrm{P}_{\mathrm{R}}=155.7 \mathrm{~W}$

1. Selection of Motor

Hp Rpm - 1000 $\mu$

373w Design Data

Design of V Bell Pulley

$\mathrm{P}_{1}=\mathrm{P}_{\mathrm{R}} * \mathrm{~K}_{1}$

$\mathrm{P}_{\mathrm{R}}=1 / 2 \mathrm{Hp}=0.373 \mathrm{~K} \mathrm{w}$

$\mathrm{K}_{1}=$ load Factor

Take $\mathrm{K}_{1}=1.15$

Design Power $=0.373 * 1.15$

$$
=0.429 \mathrm{k} \mathrm{w}
$$

Specification Belt

Cross Section - A

Nominal Width $-13 \mathrm{~mm}$

Nominal thick area $=8 \mathrm{~mm}$

Recommended Pulley dia. $-\mathrm{P}_{1}=50 \mathrm{~mm}$

Velocity ratio $=\mathrm{N}_{1} / \mathrm{N}_{2}=1000 / 220.26=4.54$

$\therefore \mathrm{V}_{\mathrm{R}}=\mathrm{N}_{1} / \mathrm{N}_{2}=\mathrm{D}_{2} / \mathrm{D}_{1}$

$\mathrm{D}_{2}=\mathrm{V}_{\mathrm{R}} * \mathrm{D}_{1}=4.54 * 550$

$=227 \mathrm{~mm}$

$\cong 230 \mathrm{~mm}$

Peripheral Velocity

$\mathrm{V}_{\mathrm{p}}=\frac{\pi \mathrm{D}_{1} \mathrm{~N}_{1}}{60}=\frac{(\pi * .050 * 1000)}{60}=2.61 \mathrm{~m} / \mathrm{s}$

Centre Distance

$\mathrm{C}=\mathrm{D}_{1}+\mathrm{D}_{2}=2(50+230)=560 \mathrm{~mm}$

Length of belt

$\mathrm{C}=2 \mathrm{C}+\frac{\pi}{2}\left(\mathrm{D}_{1}+\mathrm{D}_{2}\right)+\left(\frac{\mathrm{D}_{2}-\mathrm{D}_{1}}{4 \mathrm{C}}\right)^{2}$

$=2 * 560+\frac{\pi}{2}(50+230)+\left(\frac{(230-050)}{4 * 560}\right)^{2}$

$=1120+439.8229+14.46$

$=1574288$

$=10574 \mathrm{~m}$

Angle of lap $\theta$ 
Smaller Pulley $\theta_{1}=\pi-\left(\frac{\mathrm{D}_{2-\mathrm{D}_{1}}}{\mathrm{C}}\right)=\pi\left(\frac{230-50}{560}\right)$

$=282.82 \mathrm{rod}$

Longer Pulley $\theta_{2}=\pi+\left(\frac{D_{2-D_{1}}}{C}\right)=3.46 \operatorname{Rod}$

Power per Belt

(Power/ Belt $)=($ F w - F c $) \frac{e^{\mathrm{uQ} / \sin \left(\frac{\alpha}{2}\right)-1}}{\mathrm{e}^{\mathrm{uQ} / \sin \left(\frac{\alpha}{2}\right)}} \mathrm{vp}$

For A type Belt

$\mathrm{W}=13$

$\mathrm{F} \mathrm{w}=\mathrm{w}^{2}=13^{2}=169 \mathrm{~N}$

$\mathrm{Fc}=\mathrm{Kc}(\mathrm{V} \mathrm{p} / \tau)^{2}$

Take $\mathrm{Kc}=2.52$

$\mathrm{F} \mathrm{c}=2.52(2.61 / 5)^{2}$

$\mathrm{F} \mathrm{c}=0.6866 \mathrm{~N}$

$\mu=0.3 \quad \theta=3.46$ (largepulley)

$\alpha=0.3$

$($ Power $/$ Belt $)=(169-0.6866) \frac{\mathrm{e}^{0.3 * 3.46} / \sin \left(\frac{34}{2}\right)-1}{\mathrm{e}^{0.3 * 346} / \sin \left(\frac{34}{2}\right)} * 2.61$

$=393.80 \mathrm{w}=0.3938 \mathrm{k} \mathrm{w}$

No of

$(\mathrm{N})=\frac{\text { Designpower }}{\text { Powerperbelt }}=\frac{0.429}{0.3936}$

$=1.089 \cong 1$

No off $=1$

Bending load

$\mathrm{F} \mathrm{b}=\mathrm{Kb} / \mathrm{D}$

$\mathrm{K} \mathrm{b}=$ bending stress factor $=17.6^{*} 13^{3}$

Small Pulley $\mathrm{D}_{1}$

$\mathrm{F} \mathrm{b}=\left(17.6 * 10^{3} / 50\right)$

$=352 \mathrm{~N}$

Large pulley $\mathrm{D}_{2}$

$\mathrm{F} \mathrm{b}=\left(17.6^{*} 10^{13} / 230\right)$

$=76.52 \mathrm{~N}$

$$
\mathrm{F} \mathrm{b}=352 \mathrm{~N}
$$

Belt tension ratio

$\left(\mathrm{T} 1 / \mathrm{T}_{2}\right)=\mathrm{e}^{\mathrm{uQ} / \sin \left(\frac{\mathrm{a}}{2}\right)}$

$=\mathrm{e}^{0.3 * 3.46} / \sin \left(\frac{34}{2}\right)$

$\left(\mathrm{T} 1 / \mathrm{T}_{2}\right)=9.65$

Belt tension $\left(\mathrm{T} 1 / \mathrm{T}_{2}\right)=\mathrm{Pd} / \mathrm{V} \mathrm{p}$

$=\frac{0.429}{2.61}$

$=164.36$

But, $\frac{\mathrm{T}_{1}}{\mathrm{~T}_{2}}=9.65$

$\mathrm{T} 1=9.65 \mathrm{~T} 2$

$(9.65 \mathrm{~T} 2-\mathrm{T} 2)=164.36 \mathrm{~N}$

$\mathrm{T} 2=19 \mathrm{~N}$

$\mathrm{T} 1=183.35$

Initial Tension

$2 \sqrt{\mathrm{Ti}}=\sqrt{\mathrm{T} 1}+\sqrt{\mathrm{T} 2}$

$2 \sqrt{\mathrm{Ti}}=\sqrt{183.35}+\sqrt{15}$

$\mathrm{Ti}=80.0987 \mathrm{~N}$

Maximum total Force

$\mathrm{F} 1=\mathrm{Ti}=\mathrm{F} \mathrm{c}=\mathrm{F}$ b max

$80.0987+0.6866+352$

$=432.785 \mathrm{~N}$

Shaft Design for longer pulley

$\mathrm{T} \mathrm{d}=\frac{60 * \mathrm{p} * \mathrm{k} 1}{2 \pi \mathrm{N} 2}$

$\mathrm{P}=0.373 \mathrm{k} \mathrm{c}=373 \mathrm{w}$ 
$\mathrm{K} 1=1.75$

$\mathrm{N}_{2}=220.26 \mathrm{rpm}$

Td $-\frac{60 * 373 * 1.75}{2 * \pi * 220.26}$

$\mathrm{Td}=28.299 \mathrm{Nm}$

Maximum Stress

$\mathrm{T}_{\text {max }}=\frac{16}{\mathrm{D} 3} \sqrt{\mathrm{m}^{2}+\mathrm{Td}^{2}}$

$\mathrm{T}_{\max }=0.30$ Syt

For Shaft SAE 1030

Sty $=296 \mathrm{mpa}$

Take F.S = 2

$\mathrm{T}_{\text {max }}=0.30 * \frac{\text { syt }}{\mathrm{F} . \mathrm{S}}=0.30 * \frac{296}{2}$

$=44.4 \mathrm{~N} / \mathrm{mm}^{2}$

$=44.4 * 10^{6} \mathrm{~N} / \mathrm{m}^{2}$

Mass of Pulley, $\mathrm{M}=\mathrm{SAL}$

$M=1 / 2 \mathrm{~kg}$

$\mathrm{M}=0.5 \mathrm{~kg}$

$\mathrm{W}=4.905 \mathrm{~N}$

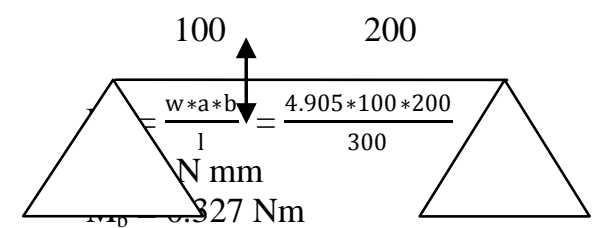

$\mathrm{T}_{\text {max }}=\frac{16}{\pi \mathrm{D} 3} \sqrt{\mathrm{m}^{2}+\mathrm{Td}^{2}}$

$44.4 * 10^{6}=\frac{16}{\pi \mathrm{D} 3} \sqrt{0.327^{2}+28.299^{2}}$

$\mathrm{D}=0.01480 \mathrm{~m}$

$\mathrm{P}=14.806 \mathrm{~mm}$

$=16 \mathrm{~mm}$

Smaller pulley specification

For section A

$\mathrm{Lp}=11 \mathrm{~mm}$

$\mathrm{b}=3.3 \mathrm{~mm}$

$\mathrm{h}=8.7 \mathrm{~mm}$

$\mathrm{e}=15 \pm 0.3 \mathrm{~mm}$

$\mathrm{f}=\mathrm{q}-12 \mathrm{~mm} \cong 10.5 \mathrm{~mm}$

$\mathrm{D}_{\mathrm{p}}=50 \mathrm{~mm}$

$\alpha=3^{\circ}$

Width of pulley

$\mathrm{W}=(\mathrm{n}-1)+2 \mathrm{f}$

$=(1-1) * 15+(2 * 10.5)$

$\mathrm{W}=21 \mathrm{~mm}$

No off set I

Dia. $\mathrm{Hub}=1.5 \mathrm{D}_{5}+25=(105 * 20)+25$

$\mathrm{D}_{\mathrm{n}}=55 \mathrm{~mm}$

Length of hub $=1.5 \mathrm{D}_{5}=1.5 * 20$

$=30 \mathrm{~mm}$

Longer pulley

Da. Of Hub $=1.5 * 16+25$

$=49 \mathrm{~mm}$

Length of $\mathrm{Hub}=1.5 * 16=24 \mathrm{~mm}$

\section{PROCESS SHEET}

I. PART NAME: Frame

MATERIAL: Mild Steel 


\section{WEIGHT: 5 Kg. QUANTITY: 1}

\begin{tabular}{|l|l|l|l|}
\hline Sr. Number & OPERATION & MACHINE & TIME \\
\hline 1) & Cutting the material as our required size. & Power chop saw & 50 Minute \\
\hline 2) & Finishing the edges with grinder using grinding wheel & Hand grinder & 20 minutes \\
\hline 3$)$ & $\begin{array}{l}\text { Welding square pipes of different lengths to make } \\
\text { frame }\end{array}$ & Electric arc Welding & 120 Minute \\
\hline 4$)$ & $\begin{array}{l}\text { Finishing the welded joints with hand grinder using } \\
\text { grinding wheel }\end{array}$ & Hand grinder & 20 minutes \\
\hline 5$)$ & Cutting material for support of load & Power chop saw & 20 minutes \\
\hline 6$)$ & Welding the material on top side & Electric arc Welding & 30 minutes \\
\hline
\end{tabular}

II. PART NAME: Base for motor

MATERIAL: Mild Steel

QUANTITY: 1

\begin{tabular}{|l|l|l|l|}
\hline SR.NO & OPERATION & MACHINE & TIME \\
\hline 1$)$ & Cutting the material & Band saw & 15 Minute \\
\hline 2$)$ & Weld the cut material to make a frame & Arc welding machine & 10 Minute \\
\hline 3$)$ & Drilling for motor bolt & Hand drill machine & 10 Minute \\
\hline 4$)$ & Weld the base to the frame & Arc welding machine & 10 in \\
\hline
\end{tabular}

III. PART NAME: Attachments for pedestal bearing

QUANTITY: 4

\begin{tabular}{|l|l|l|c|}
\hline SR.NO & OPERATION & MACHINE & TIME \\
\hline 1$)$ & Tap on the angle according distance & Manually & 5 Minute \\
\hline 2$)$ & Drill on angle & Hand drill machine & 10 inute \\
\hline
\end{tabular}

IV. PART NAME: Shaft

MATERIAL: Mild Steel

QUANTITY: 1

\begin{tabular}{|l|l|l|l|}
\hline SR.NO. & OPERATION & MACHINE & TIME \\
\hline 1 & Turning the shaft on lathe as per bearing size & lathe & 15MIN \\
\hline 2 & Threading at one end & lathe & 10MIN \\
\hline
\end{tabular}

V. PART NAME: Hopper \& hopper frame

MATERIL: GI sheet

WEIGHT: $0.5 \mathrm{Kg}$.

QUANTITY: 1

\begin{tabular}{|l|l|l|l|}
\hline Sr. Number & OPERATION & MACHINE & TIME \\
\hline 1$)$ & $\begin{array}{l}\text { Cutting the GI sheet our required size. and } \\
\text { cut the angle for hopper frame }\end{array}$ & Power chop saw & 50 Minute \\
\hline 2$)$ & Bend the sheet & Manually & 0Minute \\
\hline 3$)$ & $\begin{array}{l}\text { Weld the bend aligned sheet } \\
\text { And weld the angle }\end{array}$ & Arc welding & 20 minutes \\
\hline 4$)$ & Welding the frame on top side & Electric arc Welding & 15 minutes \\
\hline
\end{tabular}

FACTORS DETERMINING THE SELECTION OF MATERIALS

The various factors which determine the choice of material are discussed below.

\section{PROPERTIES}

The material selected must possess the necessary properties for the proposed application. The various requirements to be satisfied can be weight, surface finish, rigidity, ability to withstand environmental attack from chemicals, service life, reliability etc.

The following four types of principle properties of materials decisively affect their selection 


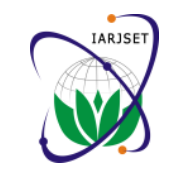

\section{IARJSET

- Physical

- Mechanical

- From manufacturing point of view

- Chemical

The various physical properties concerned are melting point, thermal Conductivity, specific heat, coefficient of thermal expansion, specific gravity, electrical conductivity, magnetic purposes etc. The various Mechanical Properties Concerned are strength in tensile, Compressive shear, bending, torsion and buckling load, fatigue resistance, impact resistance, elastic limit, endurance limit, and modulus of elasticity, hardness, wear resistance and sliding properties.

The various properties concerned from the manufacturing point of view are:

- Cast ability

- Weld ability

- Surface properties

- Shrinkage

- Deep drawing etc.

\section{MANUFACTURING COST}

Sometimes the demand for lowest possible manufacturing cost or surface qualities obtainable by the application of suitable coating substances may demand the use of special materials.

\section{QUALITY REQUIRED}

This generally affects the manufacturing process and ultimately the material. For example, it would never be desirable to go casting of a less number of components which can be fabricated much more economically by welding or hand forging the steel.

\section{AVAILABILITY OF MATERIAL}

Some materials may be scarce or in short supply, it then becomes obligatory for the designer to use some other material which though may not be a perfect substitute for the material designed. The delivery of materials and the delivery date of product should also be kept in mind.

\section{SPACE CONSIDERATION}

Sometimes high strength materials have to be selected because the forces involved are high and space limitations are there.

\section{COST ESTIMATION:-}

Cost estimation may be defined as the process of forecasting the expenses that must be incurred to manufacture a product. These expenses take into a consideration all expenditure involved in a design and manufacturing with all related services facilities such as pattern making, tool, making as well as a portion of the general administrative and selling costs.

\section{PURPOSE OF COST ESTIMATION}

1. To determine the selling price of a product for a quotation or contract so as to ensure a reasonable profit to the company.

2. Check the quotation supplied by vendors.

3. Determine the most economical process or material to manufacture the product.

4. To determine standards of production performance that may be used to control the cost.

\section{TYPES OF COST ESTIMATION}

\section{Material cost}

2. Machining cost

\section{Material Cost Estimation}

Material cost estimation gives the total amount required to collect the raw material which has to be processed or fabricated to desired size and functioning of the components.

These materials are divided into two categories.

1. Material for fabrication:

In this the material in obtained in raw condition and is manufactured or processed to finished size for proper functioning of the component. 


\section{Standard purchased parts:}

This includes the parts which was readily available in the market like allen screws etc. A list is forecast by the estimation stating the quality, size and

Standard parts, the weight of raw material and cost per kg. For the fabricated parts.

\section{MACHINING COST ESTIMATION}

This cost estimation is an attempt to forecast the total expenses that may include manufacturing apart from material cost. Cost estimation of manufactured parts can be considered as judgment on and after careful consideration which includes labour, material and factory services required to produce the required part.

\section{PROCEDURE FOR CALCULATION OF MATERIAL COST}

The general procedure for calculation of material cost estimation is after designing a project,

1. A bill of material is prepared which is divided into two categories.

iFabricated components

ii. Stand. ard purchased components

2. The rates of all standard items are taken and added up.

3. Cost of raw material purchased taken and added up.

\section{SAFETY PRECAUTIONS}

The following points should be considered for the safe operation of machineand to avoid accidents:-

1. All the parts of the machine should be checked to be in perfect alignment.

2. All the nuts and bolts should be perfectly tightened.

3. The operating switch should be located at convenient distance from the operator so as to control the machine easily.

4. The inspection and maintenance of the machine should be done from time to time.

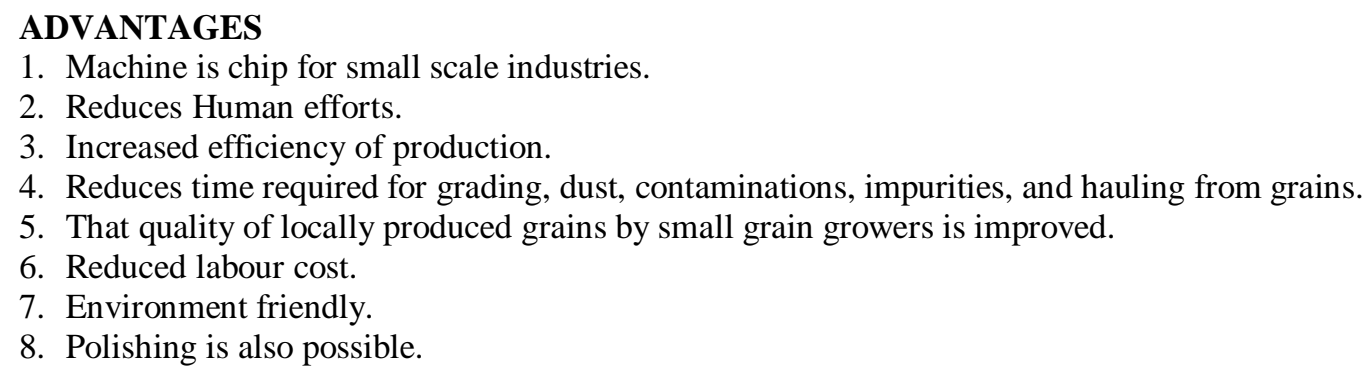

\section{DISADVANTAGES}

1. Slight Heavy structure.

2. Periodic maintenance and cleaning required.

\section{FUTURE SCOPE}

1. Mass production for the sales.

2. Polishing process will be improved as per market demand.

\section{REFERENCES}

[1] Chethana T. V and D. Ramesh, "Fabrication of Pedal Operated Grain Cleaner", Golden Research Thoughts, Original Article, Volume 3, Issue 12, June 2014, ISSN:-2231-5063 PP 1-8.

[2] NAGESH S. And Dr. S.N. LAKSHMINARASIMHAN, "Development of Grain Separator Machine", International Journal of Engineering Research-Online, A Peer Reviewed International Journal, Vol. 2, Issue. 6, 2014, ISSN: 2321-7758, PP 161-167.

[3] S. V. Irtwange, "Design, fabrication and performance of a motorized cowpea thresher for Nigerian small-scale farmers", African Journal of Agricultural Research Vol. 4 (12), pp. 1383-1391, December 2009, ISSN 1991-637X, PP 1383-1391.

[4] U.S. Muhammad, L.G. Abubakar, M. Isiaka and R.M. Davies, "Design and evaluation of a cleaning machine", Applied Science Reports, Copyright @ PSCI Publications 1 (3), 2013: PP 62-66.

[5] MeeshaPunn and NidhiBhalla, "Classification of Wheat Grains Using Machine Algorithms", International Journal of Science and Research (IJSR), India Online ISSN: 2319-7064, Volume 2, Issue 8, August 2013, PP 363-366.

[6] Amitabha Ghosh, Ashok Kumar Malik, Theory of Mechanism and Machines, third Edition, Affiliated press, Pvt. Ltd, New Delhi 1998.

[7] Shigley, Joseph Edward, Theory of Machines and Mechanisms, Tata McGraw Hill, New York, 2003

[8] A Text Book of Mechanical System Design, FarazdakHaideri, Third Edition, Chapter 2, Page No. 149 - 241.

[9] Mechanics of Materials I, Third Edition, E. J. Hearn, University of Warwick, United Kingdom, Chapter 1, Page No. $1-8$.

[10] Mechanical Vibrations, ThammaiahGowda, Jagadeesha T, D. V. Girish, Tata Mcgraw Hill Education Private Limited, Page No. 44, Topic Spring Element.

[11] Strength of Materials, S. Ramamrutham, R. Narayanan, DhanpatRai Publication Company, Page No. 116-118. 